\title{
Haşhaş Tohumu Yağından Elde Edilen Biyodizelin Motor Parametrelerine Etkisi
}

\author{
Süleyman Şimşek ${ }^{1 *}$, Alper Aydın², Hatice Şimşek ${ }^{3}$ \\ 1* İstanbul Aydın Üniversitesi, Mühendislik Fakültesi, Makine Mühendisliği Bölümü, İstanbul, Türkiye, (ORCID: 0000-0002-0593-8036), \\ suleymansimsek@aydin.edu.tr \\ 2 İstanbul Aydın Üniversitesi, Fen Bilimleri Fakültesi, Makine Mühendisliği Bölümü, İstanbul, Türkiye (ORCID: 0000-0002-0076-5367), \\ alper1044@gmail.com \\ ${ }^{3}$ Tekirdağ Namık Üniversitesi, Teknik Bilimler Meslek Yüksekokulu, Makine ve Metal Teknolojileri Bölümü, İstanbul, Türkiye (ORCID: 0000-0003-0041-3406), \\ h.simsek@nku.edu.tr
}

(Uluslararası Araştırma-Geliştirme ve Tasarım Konferansı - 15-18 Aralık 2021)

(DOI: 10.31590/ejosat.1045655)

ATIF/REFERENCE: Şimşek, S., Aydın, A. \& Şimşek, H. (2021). Haşhaş Tohumu Yağından Elde Edilen Biyodizelin Motor Parametrelerine Etkisi. Avrupa Bilim ve Teknoloji Dergisi, (32), 595-601.

$\ddot{O} z$

Fosil kaynaklı yakıtların oluşturduğu çevresel etkiler ve küresel ısınmaya verdiği zararlarla birlikte dünyadaki yakıt rezervlerin azalması, alternatif yakıt arayışını hızlandırmıştır. Ülkemizdeki enerji kaynaklarının \%85-90’ ithal edildiği için alternatif yakıt arayışı daha fazla öneme sahiptir. Cevreye daha az zarar veren ve kullanım ömrü daha uzun olan yenilenebilir enerji kaynakları arayışına yönelmişlerdir. Bu çalışmada, haşhaş tohumudan elde edilen haşhaş yağının transestrifikasyon yöntemi ile bodizel elde edilmiştir. Yakıt olarak motorin ile haşhaş tohum yağı yüzdesel olarak harmanlanmıştır. Deneyde dört zamanlı, tek silindirli, direk enjektörlü, hava soğutmalı bir dizel motor kullanılmıştır. Özgül yakıt tüketiminde \%34.95 $\mathrm{NO}_{\mathrm{x}}$ emisyonunda \%31,02 azalış, CO emisyonunda \%23,62 azalış, $\mathrm{CO}_{2}$ emisyonunda \%26,09 artış ve $\mathrm{HC}$ emisyonunda \%39,57 azalış tespit edilmiştir.

Anahtar Kelimeler: Biyodizel, Haşhaş yağı, Motor performansı, Egzoz emisyonu

\section{The Effect of Biodiesel Obtained from Poppy Seed Oil on Engine Parameters}

\begin{abstract}
Due to the environmental effects of fossil fuels and the damage they cause to global warming, the shortness of their reserves in the world, has accelerated the search for alternative fuels in the world. Since 85-90\% of the energy resources in our country are imported from other countries, the search for alternative fuels is more important for us. For this reason, the countries of the world and especially our country have turned to the search for renewable energy sources that are less harmful to the environment and have a longer useful life. In this study, we tested the results and emission values on the engine by mixing poppy oil, which is widely produced in our country and which we think can adapt better when mixed with diesel fuel due to its chemical properties, with diesel fuel. We compared the results found with each other. We put forward the benefits and harms of the result of our study. In specific fuel consumption, $34.95 \%$ reduction in NOx emission, 31.02\% decrease, $23.62 \%$ decrease in CO emission, $26.09 \%$ increase in CO2 emission and $39.57 \%$ decrease in $\mathrm{HC}$ emission were determined.
\end{abstract}

Keywords: Biodiesel, Poppy oil, Engine performance, Exhaust emissions

\footnotetext{
*Sorumlu Yazar: alperaydin1@stu.aydin.edu.tr
} 


\section{Giriş}

(Ozemre, 1994) Enerji, maddelerin yapısında bulunan potansiyel enerjinin çeşitli şekillerde açığa çıkmasıyla oluşan güce denir. Yakıttan elde edilen enerji ülkemizde ve dünyamızda yaşamın her alanında vazgeçilmez bir parçası olmuş ve kişisel kullanımdan sanayi alanında üretime kadar büyük bir kullanım alanına ulaşmıştır. Yakıtlardaki hammadenin kısıtlı olması ve kaynaklarının belli bir ömre sahip olması gelecekte oluşabilecek enerji krizlerinin göstergesidir. Dünyadaki bilimsel araştırmalar petrol rezervlerinin yaklaşık 2050, doğalgaz rezervinin yaklaşık 2070 ve kömür rezervlerinin yaklaşık 2150 yılında biteceğini öngöstermektedir. (Eliçin, Saçılık, \& ERDOĞAN, 2007) Bu kaynakların çevreye ve atmosfere verdiği zararlarda her geçen gün dünyamız için tehlike yaratmaya devam etmektedir. Bilindiği üzere küresel ısınmanın temel etkenlerinden biri fosil yakıtların kullanılmasından açığa çıkan karbondioksit gazı olduğunu göstermektedir.

(Karaosmanoglu, Kurt, \& Ozaktas, 2000) Ülkemiz enerji ihtiyacının yaklaşık \%85-90' inı ithal etmektedir. Enerji kaynaklarının ithal edildiği ülkelerde oluşan uluslararası dalgalanmalar ve kaynakların bazı ülkelerde yoğunlaşması o bölgelerdeki istikrarsızlıklarla beraber ülkemizde hali hazırda maliyetlerin yüksek olmasına ve gayri safî milli hasılada büyük bir yer kaplamasına sebep olmaktadır. (YÜCESU, ALTIN, \& ÇETINKAYA, 2001) Ülkemiz de gelişmiş diğer ülkeler gibi hem enerji maliyetlerini düşürmek, hem atmosfere salınan karbondioksit gazının etkilerini azaltmak için yenilenebilir enerji kaynaklarına yönelmeye başlamıştır.

(Altınsoy, 2007) Ülkemiz bir tarım ülkesi olması sebebiyle biyodizel yakıt üretimi için olduça elverişlidir. (BUDAK, BAYINDIR, \& YÜCEL) Hammadde olarak yağlı tohumlar; kolza, soya, haşhaş, ayçiçek yağı gibi bitkiler, karbonhidrat kaynaklı; patates, buğday, misır gibi, elyaf kökenli; keten, kenevir gibi, protein kaynaklı; buğday, bezelye, fasülye gibi ve hayvansal atıklar biyokütle enerjisi olarak mevcut yakıt kaynaklarına alternatif olarak kullanılabilme potansiyellerine sahiptirler. Bu sıvı biyokütle yakıtları dizel yakıtlara alternatif olarak biyodizel yakıt olarak kullanılabilirler. $\mathrm{Bu}$ yağlar dizel yakıtlarla karıştırılarak kullanılabilecekleri gibi saf ve ilave katkı maddesi olmadan da motor içerisinde kullanılabilirler.

(Cetinkaya, Ulusoy, Tekìn, \& Karaosmanoğlu, 2005). Araştırmalara göre bitkisel yağların yakıt olarak kullanılması antik misırlılar dönemine kadar uzanmaktadır. Yapılan araştırmalarda Mısırlılar aydınlatma aracı olarak hint yağı kullandıklarına dair bulgulara rastlamışlardır. (Kafadar, 2010) Bitkisel yağların yakıt olarak motor içerisinde kullanılabilmesiyle ilgili çalışmaları ise dizel motorun mucidi Rudolf Diesel tarafından 1893 yılında Almanyada gerçekleştirilmeye başlanmıştır. Rudolf Diesel yaptığ 1 çalışmalar neticesinde 1898 yılında Paris fuarında yer fistığı yağı ile çalışan motoru halka sunmuştur.

(Filiz Karaosmanoğlu, 2004) Avrupada 1988 yılında çiftçi kooperatifleri tarafindan 1988 yılında bir biyodizel tesisi kurulmuş ve yıllık 500 ton biyodizel üretilmeye başlanmıştır. İlk endüstriyel biyodizel üretim tesisi ise yine Avusturya'da kurulmuştur. $\mathrm{Bu}$ tesis yılda yaklaşık 10.000 ton üretim potansiyeline sahiptir. Biyodizel üretiminde tesisleşme zaman e-ISSN: 2148-2683 içerisinde İtalya ve Fransa gibi diğer Avrupa ülkelerinde de yaygınlaşmaya başlamıştır. (SABANCI, Mehmet, \& Yaşar, 2006) Uluslararası Enerji Enstitüsünün 1988 yılında yayımladığı Avusturya Biyoyakıtlar Enstitüsü raporunda 21 ülkede biyodizel yakıt üretildiği ve Avrupa Birliği ülkelerinin 40 tesisle yılda 1434 ton biyodizel yakıt üretimi geçekleştirdiğini sunmuştur.

(Bayraktar \& Siyalom, 2005) Avrupa Birliği 27 Kasım 2001 yılında yayımladığ $\breve{g}_{1}(2001 / 77 / E C)$ önergesinde 2010 yılında kullanılacak enerji miktarının \%22' sinin yenilenebilir enerji kaynaklarından karşılanacağını taahhüt etmiştir. (Acaroğlu, 2005) Biyodizel yakıt kullananların dizel yakıt kullananlara karşı $\% 50$ daha az $\mathrm{CO}_{2}$ vergisi ödemesi kararı alınmıştır.

Amerika Birleşik Devletlerinde Enerji Siyaseti Yasası 1992 y1lında kabul edilmiş ve bu yasayla 2000 yılında \%10, 2010 y1lında ise $\% 30$ oranında petrol yerine alternatif enerji kaynaklarının kullanılacağı yasa ile kabul edilmiştir.

(Taşyürek, 2004) Ülkemizde ilk defa 1934 yılında Atatürk Orman Çiftliğnde traktörlerin kullanılmasında denenmiş olup bu biyodizel yakıtlarla ilgili çalışmalar yapılmıştır 1970 yılında gerçekleşen enerji kriziyle birlikte ülkemizde diğer dünya ülkeleri gibi alternatif enerji kaynağı arayışlarına hız vermiştir. Özellikle de biyogaz ve biyodizel yakıtlar ile ilgili çalışmalar olsa da zaman içerisinde bu yakıtlardan vazgeçilmiştir.

Biyodizel yakıtlarla ilgili olarak ülkemizde ilk defa 20 Aralık 2003 y1lında 25322 say1lı T.C. Resmi Gazetede 5015 sayılı Petrol Piyasası Kanunu ile tanımlanmıştır. Kanunun yürürlüğe girmesinden sonra 17 Haziran 2004 yılında 25495 sayılı Resmi Gazetede yayımlanan kanunla Petrol Piyasas1 Lisans Yönetmeliği yürürlüğe girmiştir. Kanunun yürürlüğe girmesinden sonra 10 Eylül 2004 tarihinde 25579 sayılı Resmi Gazete kararıyla Petrol Piyasasında Uygulanacak Teknik Kriterler Hakkında Yönetmelik yürürlüğe girmiştir. $\mathrm{Bu}$ yönetmelikle etanol ve biyodizelin dizel yakıt veya herhangi bir yakıtla harmanlanmasını rafinerici ve dağıtıcı lisansına sahip kişilerin yapabileceği belirtilmiştir*.

Ülkemizde 25 şirket lisanslı olarak yılda yaklaşık 450 bin ton biyodizel üretimi yapmaktadır. Ancak ülkemizde üretilen yağların yemeklik yă̆ olarak kullanılmasından ve üretimin talebe yetişememesinden dolayı üretilen biyodizel yakıt üretiminin yaklaşık 300 bin tonu ithal yağlarla gerçekleştirilmektedir*.

(F Karaosmanoğlu \& Aksoy, 1994) Enerji içeriği açısından bitkisel yağlar dizel yakıtlara benzer özellikler göstermesi dikkat çekicidir. Ancak bitkisel yağların dizel yakıtlara göre 10-20 kat daha fazla viskoziye sahip olmaları enjektörlerin tıkanmasına, yağlama yağlarında problemlerin oluşmasına ve motorun ömrünü kısaltması gibi problemlere sebep olabilmekteler. (Eliçin et al., 2007; Oğuz, 2001) Bu ana sorunlar sebebiyle biyodizel yağların motor içerinde uzun süreli kullanılmaları ağır sorunlara yol açarak bakım maliyetlerini yükseltmektedir. Ancak bitkisel yağların dizel yakıtlara tercih edilebilmeleri için çözüm arayışlarıyla ya dizel motorda bazı değişikler yapılması yada bitkisel yağlara seyreltme, mikroemülsiyon oluşturma, piroliz, transesferikasyon veya süper kritik gibi uygulamalar yapılarak kullanılmalarını gerekmektedir. 
Bu çalışmada, ülkemizde bol miktarda üretimi yapılan haşhaş tohumundan yağ elde edilerek transesterifikasyon yöntemiyle biyodizel üretimi amaçlanmıştır. Üretilen biyodizelin içten yanmalı motorda egzoz emisyonlarına ve motor performansına etkisi incelenmiştir.

\section{Materyal ve Metot}

Deneylerde haşhaş tohum yağından üretilen biyodizel ve saf motorin yakıtları kullanılmıştır. Test yakıtları 3 farklı hacimsel oranlarda karıştırılarak hazırlanmıştır. Bu karışımlar D100(\%100 Dizel), BD10 (\%90 Dizel, \%10 Haşhaş Yağı) ve BD20 (\%80 Dizel, \%20 Haşhaş Yağı) oranlarında hazırlanmıştır. Yakıt testlerinin kimyasal ve fiziksel analiz sonuçları Tablo 1'de görülmektedir. $\mathrm{Bu}$ çalışmalar İstanbul Aydın Üniversitesi Mühendslik Fakültesi Motor Test Laboratuarında gerçekleştirilmiş olup yapılan çalışma sonuçları titizlikle incelenmiştir. Yakıt Test Analizleri Haşhaştan üretilen biyodizel ve motorin karışımlarının birçok özellik analizleri kimya ve enerji laboratuvarlarında TS EN 14.214 standartlarına uygun olarak TÜBITTAK MAM (Marmara Araştırma Merkezi)' nde gerçekleştirilmiş olup sonuçlar Tablo 1' de verilmiştir.

Tablo 1. Haşhaş tohumu yă̆ının fiziksel ve kimyasal özellikleri

\begin{tabular}{|c|c|c|c|}
\hline Yakıt Özellikleri & $\begin{array}{c}\% 90 \\
\text { Dizel+\%10 } \\
\text { Haşhaş } \\
\end{array}$ & $\begin{array}{c}\% 80 \\
\text { Dizel+\% } 20 \\
\text { Haşhaş } \\
\end{array}$ & Motorin \\
\hline Setan Sayısı & 53,6 & 53,1 & 56,2 \\
\hline $\begin{array}{l}\text { Üst Isıl Değer } \\
\text { (D240) cal/g }\end{array}$ & 10712 & 10538 & 10951 \\
\hline $\begin{array}{l}\text { Alt Isıl Değer } \\
(\mathrm{D} 240) \mathrm{cal} / \mathrm{g}\end{array}$ & 10102 & 9976 & 10274 \\
\hline $\begin{array}{l}\text { Yoğunluk } 15^{\circ} \mathrm{C} \\
\mathrm{kg} / \mathrm{m}^{3}\end{array}$ & 839,6 & 848,9 & 830,2 \\
\hline $\begin{array}{l}\text { Parlama Noktası } \\
{ }^{\circ} \mathrm{C} \text { ASTM D } 93\end{array}$ & 65,6 & 66,5 & 65,5 \\
\hline $\begin{array}{l}\text { Viskozite } 40{ }^{\circ} \mathrm{C} \\
\text { ASTM D } 445 \\
\mathrm{~mm}^{2} / \mathrm{s}\end{array}$ & 3,528 & 4,615 & 2,861 \\
\hline
\end{tabular}

Yapılan deneyler sırasında 3000 dev/dk.' da sabit hızda hava soğutmalı, doğal emişli, dört zamanlı, tek silindirli ve direkt enjeksiyonlu bir dizel motor kullanılarak deneyler yapılmıştır.

Test düzeneğinde yağ sıcaklık sensörü, hız sensörü, egzoz sıcaklık sensörü ve yakıt ölçüm ekipmanı motorun üzerine monte edilmiştir. Deney esnasında kullanılan motorun özellikleri Tablo 2' de gösterilmiştir. Testler öncesinde motor çalıştırılarak motor performansı ve egzoz emisyon değerleri ölçüldü. Yapılan testler sirasiyla 500, 1000, 1500, 2000, 2500 ve 3000 Watt güç yüklenerek deneyler gerçekleştirildi. Belirli oranlarda harmanlanmış Haşhaş tohumu yağı-motorin karışımının özgül yakıt tüketimi, efektif verimi $\mathrm{CO}, \mathrm{HC}, \mathrm{CO}_{2}$ ve $\mathrm{NO}_{\mathrm{x}}$ emisyon verileri tespit edilmiştir. Test düzeneğinin şematik görünümü Şekil 1'de verilmiştir. Yapılan testler esnasında kullanılan Bilsa MOD 2210 WINXP-K modelli egzoz gazı analizatörün ölçüm aralıkları ve bulunan sonuçların hassasiyetleri Tablo 3' te gösterilmiştir.
Tablo 2. Deney Motorun Özellikleri

\begin{tabular}{c|c}
\hline \multicolumn{2}{c}{ Motorun Özellikleri } \\
\hline Marka & Katana \\
\hline Model & M $178 \mathrm{FE}$ \\
\hline Çap ve Strok & 78 X $62 \mathrm{~cm}$ \\
\hline Silindir Hacmi & $296 \mathrm{~cm} 3$ \\
\hline Maksimum Beygir Gücü & 6,7 Beygir \\
\hline Motor Hızı & $3000 \mathrm{rpm}$ \\
\hline Elektrik Sistemi & $12 \mathrm{~V}-36 \mathrm{Ah}$ \\
\hline Yakıt & Dizel \\
\hline Yakıt Tankı Kapasitesi & $11 \mathrm{Lt}$ \\
\hline Yăg Tankl Kapasitesi & $1.1 \mathrm{Lt}$ \\
\hline
\end{tabular}

Tablo 3. Egzoz Gazı Analizatörünün Ölçüm Aralıklarl ve Hassasiyetleri

\begin{tabular}{c|c|c}
\hline Değişken & Ölçüm Aralı̆̆ı & Kesinlik \\
\hline$C O$ & $\% 0-10.0$ hacmen & $\% 0,00$ \\
\hline$L a m b d a$ & $0,5-2.00$ & 0.001 \\
\hline$N O_{x}$ & $0-5000$ & $1 \mathrm{ppm}$ \\
\hline $\mathrm{O}_{2}$ & $\% 0-10$ hacmen & $\% 0.01$ \\
\hline$H C$ & $0-10.000$ ppm hacmen & $1 \mathrm{ppm}$ \\
\hline $\mathrm{CO}_{2}$ & $\% 0-20.0$ hacmen & $\% 0,00$ \\
\hline $\mathrm{H}_{l z}$ & $0-9990$ dev/dak. & $10 \mathrm{rpm}$ \\
\hline
\end{tabular}

Şekil 1. Test Düzeneği Şematik Görünümü(Simsek \& Ozdalyan, 2018)

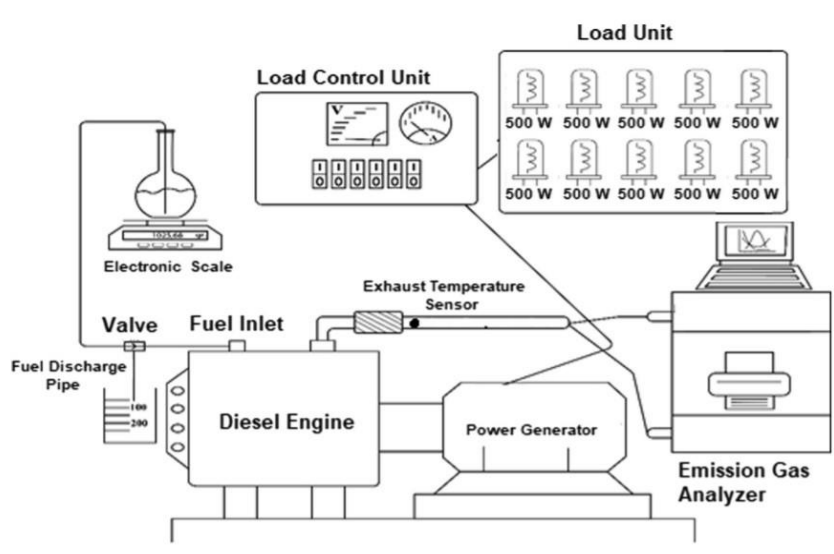




\section{Araştırma Sonuçları ve Tartışma}

\subsubsection{Efektif Verim}

(Şimşek, Özdalyan, Saygın, \& Şimşek, 2018) Efektif verim, motor içinde yanan yakıtın hangi ne kadar faydalı işe dönüştüğünü gösteren ölçümdür. Yanma olayı sonucunda oluşan enerjinin büyük bölümü yağlama, soğutma ve egzoz gazı yoluyla motordan atılırlar ancak geri kalan enerji motor için güce dönüştürülür. Yaptığımız deney için yakıtların efektif verim tablosu Şekil 2' de gösterilmiştir. BD10 ve BD20 yakıt karışımlarının efektif verimlerini D100 yakıtıyla karşılaştırırsak, BD10 yakıt karışımı \%1,87 oranında arttığı, BD20 yakıt karışımına göre ise \%4,3 oranında artış gösterdiği sonucuna ulaşıllmıştır.

Karışımlar için efektif verimler;

$$
\eta=\frac{P \operatorname{ex} 3600}{B \times H u}
$$

$\eta=$ Efektif Verim

$\mathrm{P}_{\mathrm{e}}=$ Motor Gücü $(\mathrm{kW})$

$\mathrm{B}=$ Saatlik Yakıt Tüketimi (kgh)

$\mathrm{Hu}=$ Kullanılan Yakıtın Alt Isıl Değeri

formülüyle hesaplanmıştır.

\section{Şekil 2. Efektif Verim Grafiği}

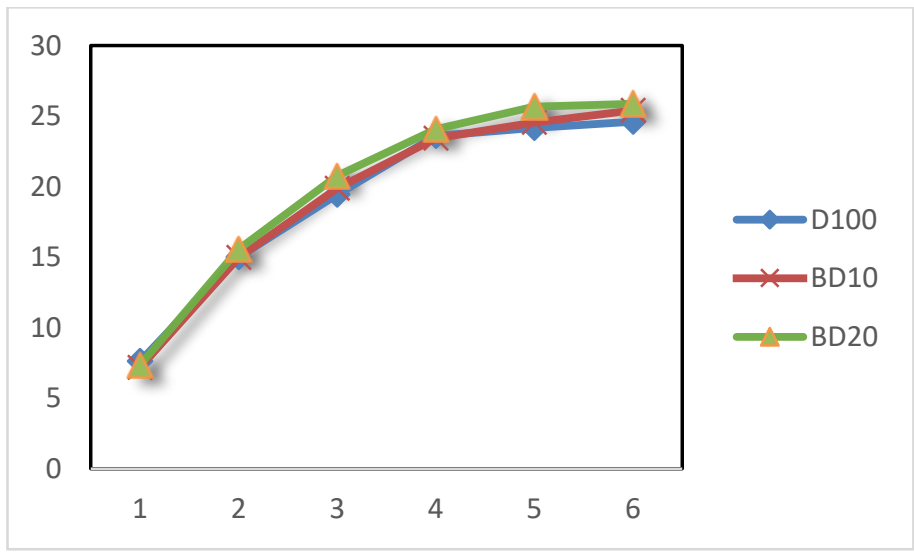

\subsection{2. Özgül Yakıt Tüketimi}

(Samet Çat, Uslu, Çelik, \& Özdalyan, 2018) Özgül yakıt tüketimi, motor içerisinde kullanılan yakıtın 1sı enerjisi halini alırken dönüşen enerjinin krank mili üzerindeki etkisini gösteren değerdir. Yani birim güç için kullanılan yakıt miktarıdır. Yaptığımız deney için motor içerisinde kullanılan özgül yakıt tüketimleri grafiği Şekil 3' da gösterilmiştir. Özgül Yakıt Tüketiminde biyodizel yakıt karışımları; tüm yüklerde ortalama olarak motorin yakıtına göre sırasıyla \%22,2, \%34,95 artış tespit edilmiştir. Biyodizelin alt 1 sıl değerinin motorine nazaran daha düşük olması, aynı gücü sağlayabilmek için silindir içerisine daha fazla yakıt püskürtülmesini gerektirmiştir ve bu sebepten özgül yakıt tüketiminde artış tespit edilmiştir.

$$
b e=\frac{B x 1000}{P_{\mathrm{e}}}
$$

be $=$ Özgül Yakıt Tüketimi $(\mathrm{g} / \mathrm{kWh})$

\subsection{Araştırma Sonuçları}

$\mathrm{B}=$ Saatlik Yakıt Tüketimi $(\mathrm{kgh})$

$\mathrm{P}_{\mathrm{e}}=$ Motor Gücü $(\mathrm{kW})$

formülüyle hesaplanmıştır.

Şekil 3. Özgül Yakıt Tüketimi Grafiği

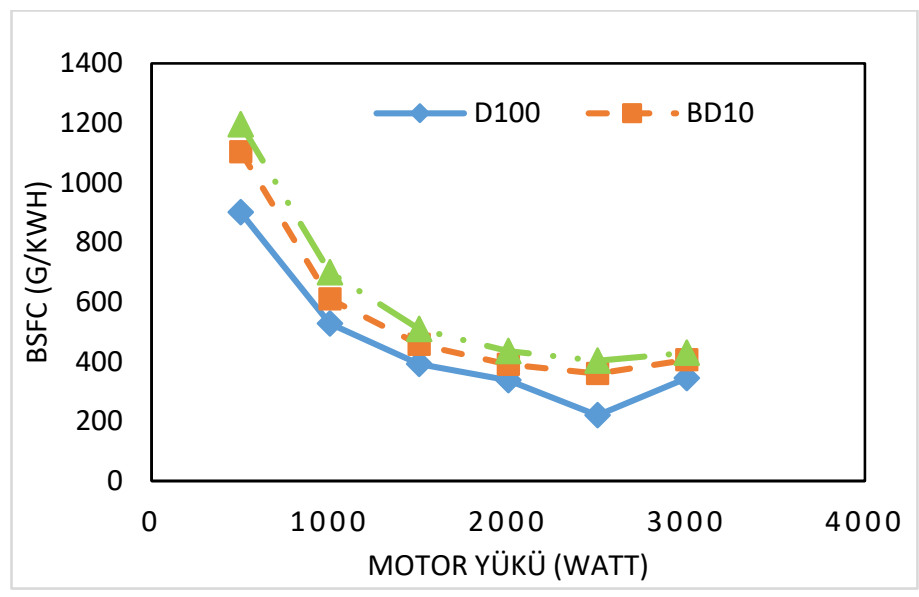

\subsubsection{CO Emisyonlart}

Testler esnasında üç farklı yakıtın çeşitli devirlerde motor yükleriyle test edilmesi sonucunda CO grafiği Şekil 4' de gösterilmiştir. Deney esnasında alınan bütün $\mathrm{CO}$ emisyon değerleri birbirine benzerlik göstermiştir. Ancak 1000 watt' a ulaşıldıktan sonra CO verilerinde farklılıklar belirginleşmeye başladı. Deney esnasında uygulanan en yüksek güç olan 3000 watt da en yüksek CO emisyon değerine sahip karışımın BD20 olduğu sonucuna ulaşılmıştır. BD10 yakıt karışımının 3000 watt'ta $\mathrm{CO}$ emisyonu değeri BD20 yakıt karışımının değerine yakın çıksada daha düşük bir değere sahip olduğu ve en düşük değere ise D100 yakıtı kullanıldığında elde edilebildiği sonucuna ulaşılmıştır. CO emisyonları esasen eksik yanma ürünü olarak oluşur. Genelde oksijen eksikliğinden kaynaklı olarak $\mathrm{C}$ atomları $\mathrm{CO}_{2}$ yerine $\mathrm{CO}$ emisyonlarını artar. Dizel motorlar için setan indeksinin yüksek olması önemli bir parametredir ve yanmayı iyileştirir. Motor içerisinde tam yanma gerçekleşir ve $\mathrm{CO}_{2}$ emisyonunda artış gerçekleşirse $\mathrm{CO}$ emisyonunda düşme gerçekleşmiş olur. Motorun yüksek devirlere hızla ulaşması ve yeterli karışımın gerçekleşmemesi durumunda CO emisyon değerinin artacağı düşünülmektedir. CO emisyonunda biyodizel yakıt karışımları; tüm yüklerde ortalama olarak motorin yakıtına göre sırasıyla \%14,9, \%23,62 azalış tespit edilmiştir. Biyodizel içeriğinde oksijen bulundurmasından dolayı yanma iyileşmiş ve $\mathrm{CO}$ emisyonunda azalış sağlanmıştır. 


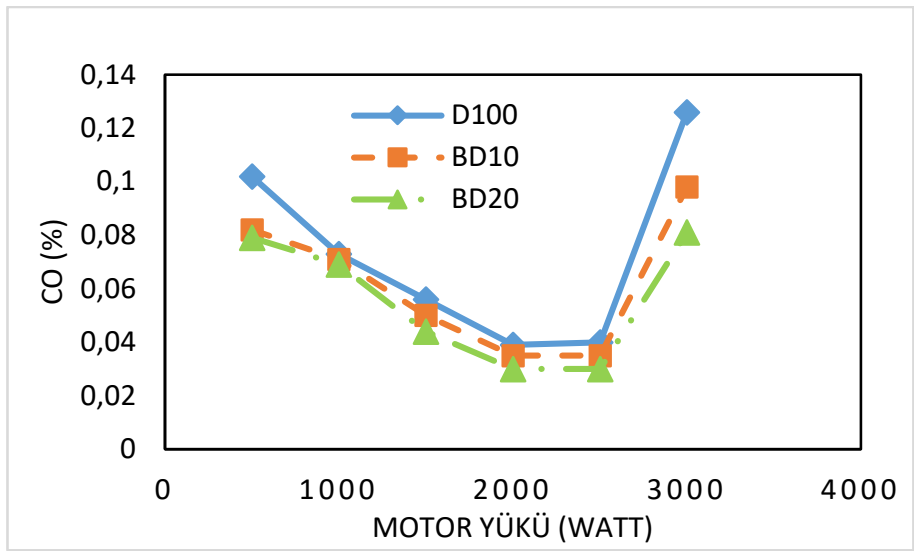

Şekil 4. CO Emisyon Grafiği

\subsection{4. $\mathrm{CO}_{2}$ Emisyonlart}

$\mathrm{CO}_{2}$ emisyonları ve $\mathrm{CO}$ emisyonlarının oluşumları esasen birbirine zıt yapıya sahiptir. Ürün egzozdan dışarı atılırken tam yanma gerçekleşerek atılırsa $\mathrm{CO}_{2}$ meydana gelir. Ürün tam yanma gerçekleşmeden egzozdan atılırsa $\mathrm{CO}$ emisyonu meydana gelmiş olur. $\mathrm{Bu}$ sebeple yanma olayında $\mathrm{CO}_{2}$ emisyonu artarken $\mathrm{CO}$ emisyonu azalmaktadır. Yani birbirlerine ters olarak sonuç vermektedirler. Motor içerisinde kullandığımız D100, BD10 ve BD20 karışımları için $\mathrm{CO}_{2}$ emisyonlarının grafiği Şekil 5'de gösterilmiştir. Yanma olayından anlaşıldığı kadarıyla biyodizel yakıt karışımlarında BD10 yakıt karışımının setan sayısının BD20 yakıt karışımına oranla setan sayısının daha yüksek olması sebebiyle $\mathrm{CO}_{2}$ emisyon değerlerinin $\mathrm{BD} 10$ yakıt karışımında daha düşük olması beklenmektedir. Şekil 5' daki grafik sonuçlarından gördüğümüz kadarıyla beklentilerimizi karşılayan sonuçlara ulaşılıştır. Yaptığımız testler sonucunda yine $\mathrm{CO}_{2}$ emisyon değerlerinin $\mathrm{CO}$ emisyon değerleri üzerinde olumsuz etkiler oluşturduğu görülmüştür. $\mathrm{CO}_{2}$ emisyonunda biyodizel yakıt karışımları; tüm yüklerde ortalama olarak motorin yakıtına göre sırasıyla \%13,27, \%26,09 artış tespit edilmiştir. Biyodizelin oksijen seviyesinden dolayı açığa çıkan sağlanmış ve bu sebepten daha iyi yanma gerçekleşmiş ve $\mathrm{HC}$ emisyonu azalmıştır.

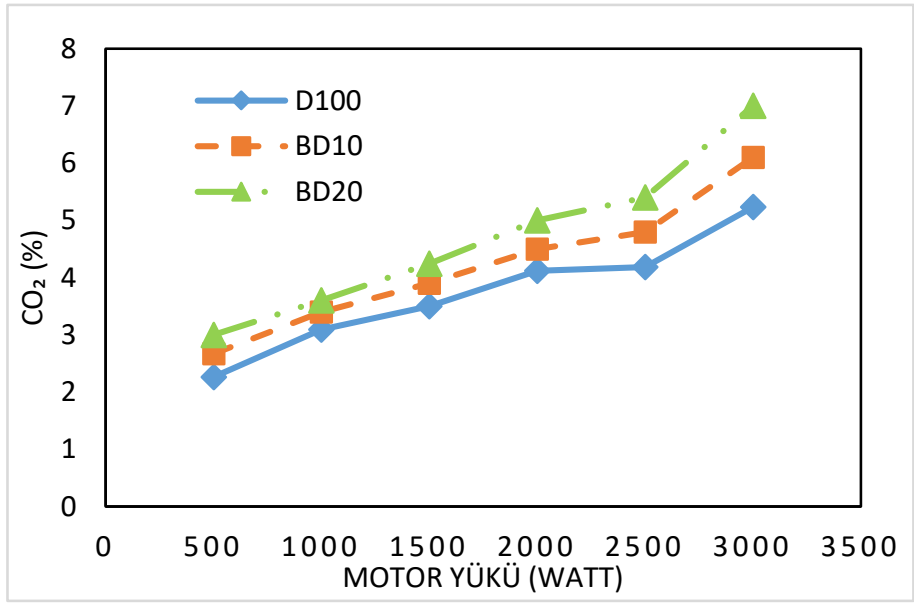

Şekil 5. $\mathrm{CO}_{2}$ Grafiği

\subsubsection{HC Emisyonlart}

$\mathrm{HC}$ emisyonları da $\mathrm{CO}$ emisyonları gibi motordan atılan eksik yanma ürünüdür. $\mathrm{HC}$ emisyonları, motor içerisinde silindire enjekte edilen yakıtın yanma reaksiyonlarına katılmadan egzoz gazıyla motordan atılmasıyla ortaya çıkar. Motor içindeki silindirlerin bazı bölgelerinde oksijen oranının düşük olmasından dolayı HC emisyonları ortaya çıkar. Yaptığımız deney sonuçlarında 3 farklı yakıt için motor içerisinde oluşan HC emisyonları grafiği Şekil 6' de gösterilmiştir. D100 yakıt karışımının BD20 biyodizel yakıt karışımına göre setan sayısının yüksek olmasından kaynaklı $\mathrm{HC}$ emisyon değerleri daha düşük seviyede çıkmıştır. D100 yakıtının viskozite değeri BD20 yakıt karışımından daha yüksek olduğundan D100 yakıt karışımının silindire püskürtülmesi daha kolay olmaktadır. Bu nedenle daha kolay homojen yakıt yanma olayı gerçekleşir. Motorda oluşan yükün etkisi incelendiğinde hava-yakıt karışımında oksijen miktarının yetersiz olduğu ve bu durumda da oksijen yetersizliğinden kaynaklı silindir içine daha fazla yakıt püskürtüldüğü ve HC emisyonlarında artış görüldüğü sonucuna ulaşılmıştır. D100 yakıt karışımının içerdiği oksijen oranı nedeniyle BD20 yakıt karışımına oranla $\mathrm{HC}$ değerlerinin daha düşük olduğu sonucuna ulaşılmışıtır. $\mathrm{HC}$ emisyonunda biyodizel yakıt karışımları; tüm yüklerde ortalama olarak motorin yakıtına göre sırasıyla \%31,37, \%39,57 azalıs tespit edilmiştir. Biyodizel içeriğindeki oksijen silindir içerisinde oksidasyon sağlanmış ve bu sebepten daha iyi yanma gerçekleşmiş ve $\mathrm{HC}$ emisyonu azalmıştır.

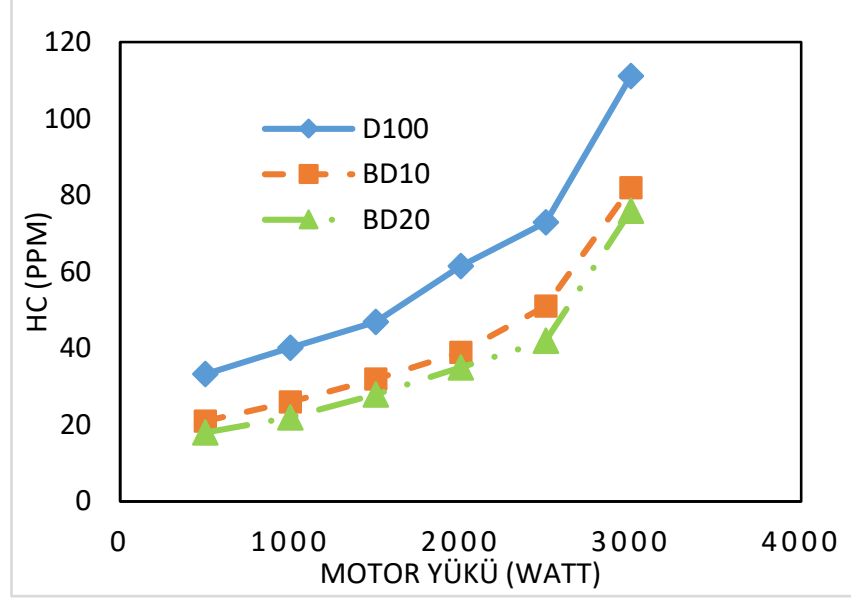

Şekil 6. HC Grafiği

\subsubsection{NO Emisyonlart}

İçten yanmalı motorlar, yakıtı yakmak için oksijene ihtiyaç duyarlar. Oksijen atmosferimizde yaklaşık \%21 oranında bulunur ve atmosferimizin geri kalanı yaklaşık \%79 oranında nitrojendir. Motor içerisindeki silindirlerde yanma olayı gerçekleşirken oksijen ve nitrojen tepkimeye girerek $\mathrm{NO}_{x}$ emisyonunu oluştururlar. (37,38). Motor yükü arttıç̧a silindirlerin içerisindeki sıcaklıkların ciddi artışlar gösterdiği bilinmektedir. Bundan dolayı bütün test yakıtları için sıcaklık ve güç arttıkça $\mathrm{NO}_{\mathrm{x}}$ emisyonunda artış görüleceği öngörülmektedir. İki yakıt içinde yapılan deney sonuçları $\mathrm{NO}_{\mathrm{x}}$ grafikleri Şekil 7'de görülmektedir. $\mathrm{Bu}$ grafiklerde güç arttıkça $\mathrm{NO}_{x}$ değerlerinde artışlar meydana geldiği görülmüştür. $\mathrm{Bu}$ emisyonu sadece yüksek sıcaklık ve basınç değil aynı zamanda kullanılan yakıtın yoğunluğu da etkilemektedir. Motor içerisinde kullanılan yakıtın yoğun olması, motor içinde silindirlerde daha fazla yakıt oluşmasına neden olacaktır. Silindirlerde daha fazla yakııın olması bölgesel sıcaklığı arttıracağı ve $\mathrm{NO}_{\mathrm{x}}$ emisyonunu da 
arttıracağ1 düşünülmektedir. Tablo 1'de görüldüğü gibi BD10 yakıt karışımının BD20 yakıt karışımlarına göre oksijen oranlarının daha düşük olması $\mathrm{NO}_{\mathrm{x}}$ emisyon oranlarında düşük olacağı anlamına gelmektedir. Bu deneyde kullanılan D100, BD10 ve BD20 yakıt karışımlarındaki oksijen oranları her üçünde de düşük olmasına rağmen D100 yakıt karışımnda daha düşüktür. D100 yakıt karışımının yoğunluğu BD10 ve BD20 yakıt karışımına oranla daha düşük olmasından dolayı $\mathrm{NO}_{\mathrm{x}}$ emisyon değerinin daha az olduğu görülmüştür. $\mathrm{NO}_{\mathrm{x}}$ emisyonunda biyodizel yakıt karışımları; tüm yüklerde ortalama olarak motorin yakıtına göre sırasıyla \%14,48, \%31,02 azalış tespit edilmiştir. Biyodizelin alt 1sıl değerinin motorine nazaran daha düşük olmasından dolayı silindir içi sıcaklık azalmış ve $\mathrm{NO}_{\mathrm{x}}$ emisyonu azalmıştır.

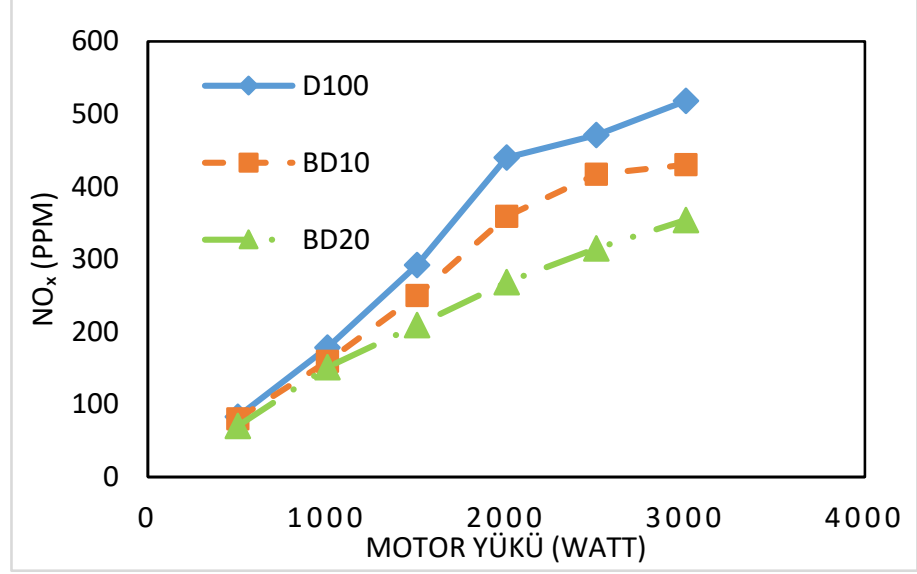

Şekil 7. $N O_{x}$ Grafiğ

\section{Sonuç}

Dizel yakıta farklı oranlarda haşhaş yağı eklenerek en verimli ve uygun yakıt karışımı hangi karışımda oluşur diye incelenmiştir. Dizel yakıt içerisine $\% 10$ ve \%20 oranlarında haşhaş yağı eklenerek tek silindirli, hava soğutmalı ve dört zamanlı bir dizel motorda çeşitli emisyon ve performans değerleri üzerindeki etkileri araştırılmıştır. Yaptığımız deneyin sonuçlarına göre;

BD10(\%90 Dizel, \%10 Haşhaş yağı) yakıt karışımı için yapılan çalışmada, setan sayılarının etkisi ile D100 yakıtının diğer yakıtlara göre özgül yakıt tüketimi daha az olduğu görülmüştür. BD10 yakıt karışımının daha iyi yanma özelliği göstermesinden kaynaklı özgül yakıt tüketimi BD20 yakıt karışımına göre daha az olduğu sonucuna ulaşılmıştır.

Yaptığımız deney sonucunda setan sayılarının farkı ve alt 1s1l değerlerindeki farktan kaynaklı D100 yakıtının efektif veriminin diğer yakıtlara göre en verimli, BD10(\%90 Dizel, \%10 Haşhaş Yağı) yakıt karışımının, BD20(\%80 Dizel, \%20 Haşhaş Yağı) yakıt karışımına göre efektif veriminin daha yüksek olduğu sonucuna ulaşılmıştır.

BD10(\%90 Dizel, \%10 Haşhaş yağı) yakıt karışımının viskozite, yoğunluk ve akışkanlık değeri BD20(\%80 Dizel, \%20 Haşhaş yağı) yakıt karışımına göre daha iyi değerlere sahip olduğu görülmüştür.
D100 yakıtının CO ve HC emisyon değerlerinin en yüksek olduğu, BD10 ve BD20 yakıt karışımları içinde setan sayısı BD10' un daha yüksek olduğu için yanma bu yakıt karışımında daha iyi sonuçlar vermiştir. Bundan dolayı da $\mathrm{CO}$ ve $\mathrm{HC}$ emisyon değerleri BD20 yakıt karışımının CO ve HC emisyon değerlerine göre daha yüksek olduğu görülmüştür.

$\mathrm{CO}$ emisyon değerlerinin azalması nedeniyle $\mathrm{CO}_{2}$ emisyon değerlerinde artmalar görülmüştür. BD10 yakıt karışımının setan sayısının daha yüksek olması sebebiyle eksik yanma daha az görülmüştür. $\mathrm{Bu}$ durumda $\mathrm{BD} 20$ ' nin $\mathrm{CO}_{2}$ emisyon değerleri diğer yakıtlara göre daha yüksek çıkmıştır.

D100 yakıt karışımının oksijen seviyesinin daha düşük olması ve yoğunluk farkları sebebiyle BD20 yakıt karışımının $\mathrm{NO}_{\mathrm{x}}$ emisyon değeri diğer yakıtlara göre daha düşük olduğu sonucuna ulaşılmıştır.

Yapılan deneyler sonucunda D100(\%100 Dizel) yakıtının özgül yakıt tüketimi ve $\mathrm{CO}_{2}$ emisyon değerleri daha düşük çıkmıştır. BD20(\%80 Dizel, \%20 Haşhaş Yağı) yakıt karışımı için $\mathrm{CO}, \mathrm{HC}$ ve $\mathrm{NO}_{\mathrm{x}}$ emisyon değerlerine göre daha düşük sonuçlar verdiği gözlenlenmiştir.

\section{Kaynakça}

Acaroğlu, M. (2005). AB ve Türkiye'de Biyodizel Potansiyeli ve Biyodizel Üretiminin Geleceği. Türkiye'de Bitkisel ve Atık Hayvansal Yağlardan Biyodizel Üretiminde Durum Saptanmasl, Ankara, 30s.

Altınsoy, A. S. (2007). Biyodizel üretimi, motorlarda kullanımı ve Türkiye'deki kaynakların incelenmesi. Fen Bilimleri Enstitüsü,

Bayraktar, S., \& Siyalom, V. Y. (2005). Türkiye'de Biyodizel ve Otomotiv. Otomotiv Sanayi Derneği.

BUDAK, N., BAYINDIR, H., \& YÜCEL, H. L. DİZEL MOTORLARDA BIYODIZEL KULLANIMININ PERFORMANS VE EGZOZ EMISYONLARI AÇISINDAN DEĞERLENDİRILMESİ.

Cetinkaya, M., Ulusoy, Y., Tekìn, Y., \& Karaosmanoğlu, F. (2005). Engine and winter road test performances of used cooking oil originated biodiesel. Energy Conversion and Management, 46(7-8), 1279-1291.

Eliçin, A. K., Saçılık, K., \& ERDOĞAN, D. (2007). Haşhaş Yağı Esterlerinin Bir Diesel Motorda Kullanım Olanaklarının Belirlenmesi. Tarımsal Mekanizasyon, 24, 5-6.

Kafadar, A. (2010). Yağlardan biyodizel eldesine etki eden faktörlerin araştırılması. Doktora Tezi, Dicle Üniversitesi,

Karaosmanoglu, F., Kurt, G., \& Ozaktas, T. (2000). Direct use of sunflower oil as a compression-ignition engine fuel. Energy Sources, 22(7), 659-672.

Karaosmanoğlu, F. (2004). Biyomotorin ve Türkiye. Motor Biyoyakıtlarl ve Türkiye”, Biyoenerji.

Karaosmanoğlu, F., \& Aksoy, H. (1994). Kullanılmış kızartma atık yağının seyreltme yöntemi ile alternatif yakıt olarak değerlendirilmesi. Türkiye, 6, 461.

Oğuz, H. (2001). Diesel yakıtı ayçiçek yağı karışımlarının Diesel motorlarında yakı olarak kullanım imkanlarının araştırılması. Selçuk Üniversitesi Fen Bilimleri Enstitüsü Yüksek Lisans Tezi.

Ozemre, A. (1994). Worlds future with respect to conventional and alternative energy resources; Konvansiyonel ve alternatif enerji kaynaklari acisindan dunyanin gelecegi. 
SABANCI, A., Mehmet, A., \& Yaşar, A. (2006). Türkiye'de Biyodizel Kullanım Olanakları. Tarım Makinaları Bilimi Dergisi, 2(1), 33-39.

Samet Çat, M. A., Uslu, S., Çelik, M. B., \& Özdalyan, B. (2018). DÜŞÜK GÜÇLÜ BİR DİZEL MOTORDA ATIK BIYODIZEL KULLANIMININ MOTOR PERFORMANS VE EMISYYNLARINA ETKİII.

Simsek, S., \& Ozdalyan, B. (2018). Improvements to the composition of fusel oil and analysis of the effects of fusel oil-gasoline blends on a spark-ignited (SI) engine's performance and emissions. Energies, 11(3), 625.

Şimşek, S., Özdalyan, B., Saygın, H., \& Şimşek, H. (2018). IÇTEN YANMALI MOTORLARDA YAKIT OLARAK FUZEL YAĞININ ELDE EDİLMESI VE ANALIZII.

Taşyürek, M. (2004). İçten Yanmalı Motorlarda Biyomotorin Yakıtlarının Geleneksel Yakıtlarla Emisyon Değerlerinin Karşılaştırılması. Yayınlanmamış Yüksek Lisans Tezi.

YÜCESU, H. S., ALTIN, R., \& ÇETINNKAYA, S. (2001). Dizel motorlarında alternatif yakıt olarak bitkisel yağ kullanımının deneysel incelenmesi. Turkish Journal of Engineering and Environmental Sciences, 25(1), 39-49. 